Article

\title{
Broad-Spectrum Anticancer Activity and Pharmacokinetic Properties of a Prenyloxy-Substituted Indeno[1,2-b]indole Derivative, Discovered as CK2 Inhibitor
}

\author{
Ehab El-Awaad ${ }^{1,2,+} \mathbb{D}$, Robin Birus ${ }^{1,+} \mathbb{D}$, Christelle Marminon ${ }^{3} \mathbb{D}$, Zouhair Bouaziz ${ }^{4}$, Laurens Ballentin ${ }^{1}$, \\ Dagmar Aichele $^{1}$, Marc Le Borgne ${ }^{3, * \mathbb{D}}$ and Joachim Jose ${ }^{1, * \text { (D) }}$
}

1 Institut für Pharmazeutische und Medizinische Chemie, PharmaCampus, Westfälische Wilhelms-Universität Münster, Corrensstr. 48, 48149 Münster, Germany; ehab.elawaad@uni-muenster.de (E.E.-A.); robin.birus@uni-muenster.de (R.B.); laurens.ballentin@uni-muenster.de (L.B.); dagmar.aichele@uni-muenster.de (D.A.)

2 Department of Pharmacology, Faculty of Medicine, Assiut University, Assiut 71515, Egypt

3 Small Molecules for Biological Targets Team, Centre de Recherche en Cancérologie de Lyon, Centre Léon Bérard, CNRS 5286, INSERM 1052, Université Claude Bernard Lyon 1, Univ Lyon, 69373 Lyon, France; christelle.marminon-davoust@univ-lyon1.fr

4 EA 4446 Bioactive Molecules and Medicinal Chemistry, Université Claude Bernard Lyon 1, Univ Lyon, 69373 Lyon, France; zouhair.bouaziz@univ-lyon1.fr

* Correspondence: marc.le-borgne@univ-lyon1.fr (M.L.B.); joachim.jose@uni-muenster.de (J.J.); Tel.: +49-251-8332200 (J.J.); Fax: +49-251-8332211 (J.J.)

Citation: El-Awaad, E.; Birus, R.; Marminon, C.; Bouaziz, Z.; Ballentin, L.; Aichele, D.; Le Borgne, M.; Jose, J. Broad-Spectrum Anticancer Activity and Pharmacokinetic Properties of a Prenyloxy-Substituted Indeno[1,2- $b]$ indole Derivative, Discovered as CK2 Inhibitor. Pharmaceuticals 2021, 14, 542. https://doi.org/10.3390/ph14060542

Academic Editor: Maria

Stefania Sinicropi

Received: 29 April 2021

Accepted: 2 June 2021

Published: 5 June 2021

Publisher's Note: MDPI stays neutral with regard to jurisdictional claims in published maps and institutional affiliations.

Copyright: (c) 2021 by the authors. Licensee MDPI, Basel, Switzerland. This article is an open access article distributed under the terms and conditions of the Creative Commons Attribution (CC BY) license (https:/ / creativecommons.org/licenses/by/ $4.0 /)$.
+ They contributed equally to this work.

Abstract: Protein kinase CK2 is involved in regulating cellular processes, such as cell cycle, proliferation, migration, and apoptosis, making it an attractive anticancer target. We previously described a prenyloxy-substituted indeno[1,2- $b$ ]indole (5-isopropyl-4-(3-methylbut-2enyloxy)-5,6,7,8-tetrahydroindeno[1,2-b]indole-9,10-dione (4p)) as a very potent inhibitor of CK2 holoenzyme $\left(\mathrm{IC}_{50}=25 \mathrm{nM}\right)$. Here, we report the broad-spectrum anticancer activity of $4 \mathbf{p}$ and provide substantial progress on its pharmacokinetic properties. Using a cell-based CK2 activity assay and live-cell imaging of cultured A431, A549, and LNCaP cancer cell lines, cellular CK2 target engagement was shown as well as strong antiproliferative, anti-migratory and apoptosis-inducing effects of $\mathbf{4} \mathbf{p}$. Furthermore, evidence was found for the ability of $\mathbf{4 p}$ to disrupt A549 spheroid cohesion. A series of LC-MS/MS experiments revealed high and rapid cellular uptake (intracellular concentration is approximately $5 \mu \mathrm{M}$ after $1 \mathrm{~h}$ incubation) and low metabolic stability of $4 \mathbf{p}$. These results point to the value of $4 p$ as a potent CK2 inhibitor with promising anticancer activities and should trigger future medicinal chemistry efforts to improve the drug-like properties of this compound.

Keywords: CK2 inhibitor; indeno[1,2-b]indole; anticancer; pharmacokinetics; LC-MS

\section{Introduction}

Human protein kinase CK2, originally named "Casein Kinase II" [1], is a ubiquitously expressed serine/threonine kinase that phosphorylates several hundreds of substrates in eukaryotic cells [2-4]. This highly pleiotropic kinase is involved in the regulation of numerous cellular processes, including, among others, cell proliferation, cell survival, as well as gene transcription and translation [5-10]. Constitutive CK2 activity is essential to the cell, with knockouts of both the catalytically active CK2 $\alpha$ and the regulatory CK2 $\beta$ subunits found lethal during embryonic development [11-13]. Besides its studied roles in diseases, such as viral infections [14,15], chronic inflammation [16], and neurodegenerative disorders [17], CK2 is known to be closely associated with cancer.

In cancer cells, upregulation of CK2 expression/activity allows them to proliferate strongly and circumvent apoptosis, and therefore these malignant cells become dependent 
on high CK2 activity for their survival. Treatment with CK2 inhibitors aims to downregulate CK2 activity in cancer cells to basal constitutive levels leading to antiproliferative and proapoptotic effects in various malignancies [18-21]. On the other hand, normal cells with constitutive CK2 activity exhibit only a modest apoptosis-inducing effect in response to downregulation of CK2 [21,22]. The continuously growing body of evidence for CK2 oncogenic potential makes this protein kinase one of the most studied targets for cancer therapy in recent decades [23-25]. Furthermore, the cellular level of this enzyme can serve as a prognostic biomarker in tumor diagnostics [26].

The indeno[ $[1,2-b]$ indole scaffold (Figure $1 a$ ) is known to be an interesting framework for developing pharmacologically active compounds with anticancer activities [27,28]. Several indeno[1,2- $b]$ indole derivatives have been reported as promising type I inhibitors of CK2 [29-32]. The compound (5-isopropyl-4-(3-methylbut-2-enyloxy)-5,6,7,8tetrahydroindeno[1,2-b]indole-9,10-dione) previously described by Gozzi et al. [33] and known as $\mathbf{4 p}$ (Figure $1 \mathrm{~b}$ ), was shown to possess remarkably high in vitro inhibitory activity toward CK2 holoenzyme among indeno[1,2-b]indole derivatives. This interesting feature of $\mathbf{4 p}$ triggered a follow-up structural study to experimentally determine the prerequisites for the observed high-affinity binding of $4 p$ to CK2 [34]. X-ray structures of $4 \mathbf{p}$ with human CK2 $\alpha$ or its paralog CK2 $\alpha$ ' revealed an unusual "hydrophobicout/oxygen-in" binding mode mainly mediated by the hydrophobic interactions through the prenyloxy group and the isopropyl substituent of the aromatic four-ring system (Figure 1b) [34]. In contrast, $\mathbf{4} \mathbf{p}$ exhibited very weak inhibition of the breast cancer multidrug resistance ABCG2 transporter, an off-target for several protein kinase inhibitors, suggesting that this compound may have a satisfactory CK2 selectivity profile [33,34]. Furthermore, $4 \mathbf{p}$ was shown in these studies to exhibit a distinct antiproliferative effect at $20 \mu \mathrm{M}$ against the breast cancer cell line MCF-7 and to have a favorable intestinal absorption profile as derived from the high apparent permeability coefficient $P_{a p p}$ in Caco-2 assay $[33,34]$.

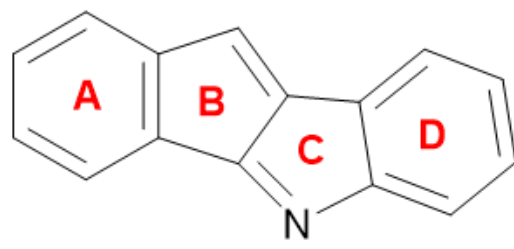

(a)

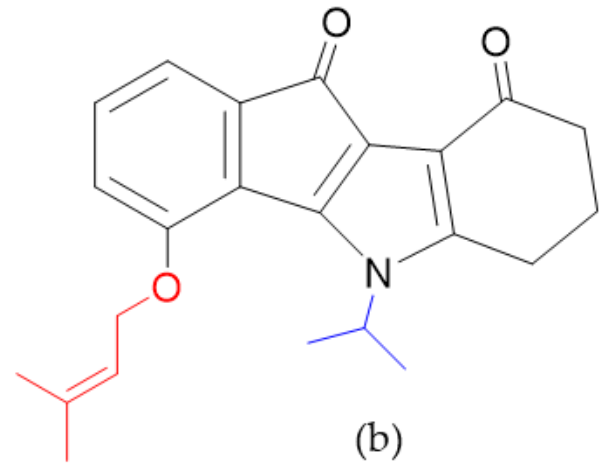

(b)

Figure 1. Structure of indeno[1,2- $b]$ indole scaffold with the corresponding labels of the aromatic four-ring system (a) and $4 \mathbf{p}$ (b) with both substitutions important for strong CK2 inhibition (i.e., prenyloxy and isopropyl groups) shown in red and blue, respectively.

Although $4 \mathrm{p}$ seems to be a promising CK2 targeting lead structure, there has been no thorough investigation of the compound's anticancer activities, its cellular target engagement, or pharmacokinetic properties. In this work, we evaluated the effects of $4 p$ on three different cell lines, namely A431, A549, and LNCaP, which are representative models of skin, lung, and prostate cancers, respectively. These cell lines were found to be dependent on CK2 for their survival as retrieved from the cancer Dependency Map project (DepMap) database (https:/ / depmap.org/portal, accessed on 15 April 2021). The ability of $4 p$ to inhibit cellular CK2 activity in these cell lines and the subsequent effects on cell proliferation, apoptosis, and migration were evaluated. Furthermore, the impact of $4 p$ on the integrity of 3D multicellular spheroids from the A549 cell line was monitored. We also 
analyzed the cellular uptake of $4 \mathbf{p}$ by A431 cells and studied its metabolic stability in vitro to get valuable insight into the pharmacokinetic properties of this compound.

\section{Results and Discussion}

\subsection{Cellular Target Engagement}

First, the suitability of A431, A549, and LNCaP cell lines to study the cellular effects of CK2 inhibitors was experimentally verified by the examination of the expression of CK2 $\alpha$ in these cell lines using immunocytochemistry. The three cell lines demonstrated strong ubiquitous CK2 $\alpha$ expression (Figure 2a), supporting the notion that these cell lines are dependent on CK2 for their survival. Next, to determine the cellular target engagement of protein kinase CK2 by $4 \mathbf{p}$, cultured cells from A431, A549, and LNCaP cell lines were treated with $4 \mathrm{p}$ at 1 and $20 \mu \mathrm{M}$ or vehicle (1\% DMSO) for $24 \mathrm{~h}$ followed by harvesting and lysing the cells. CK2 activity in the soluble fraction of the cell lysates was determined in a capillary electrophoresis-based CK2 activity assay as described before [35] utilizing the fluorescently labeled CK2 substrate FITC-RRRDDDSDD-NH2 (A representative electropherogram is shown in the Supplementary Materials, Figure S1). The ratio of the area under the curve (AUC) values for the peak of the substrate and the corresponding peak of the phosphorylated product was determined for each sample to calculate relative CK2 activity. Ratios for $4 \mathbf{p}$ treated samples were then normalized to those of control samples. As shown in Figure $2 b$, lysates from cells treated with $1 \mu \mathrm{M} 4 \mathrm{p}$ demonstrated very weak inhibition of CK2 ( $<10 \%$ for all cell lines), whereas treatment with $20 \mu \mathrm{M}$ led to statistically significant, but variable, inhibition values (44, 36, and $78 \%$ for A431, A549, and LNCaP cells, respectively). These results indicate that the determined intracellular CK2 inhibition by $4 \mathbf{p}$ is, at least, partially involved in mediating the biological effect in these cell lines. Nevertheless, there must be other off-target effects for $4 \mathbf{p}$ contributing to any observed cellular effects as well.

\subsection{Assessment of Broad-Spectrum Anticancer Activities}

\subsubsection{Inhibition of Cell Proliferation}

We previously showed the ability of $4 p$ to strongly reduce the proliferation rate of MCF7 breast cancer cell line using EdU-click assay suggesting its potential anticancer activity [33]. To comprehensively investigate the biological effects of $4 p$ on cancer cells, we examined the antiproliferative effects of this compound on cultured A431, A549, and LNCaP cells. Here, the confluence of cultured cells in 96-well plates was monitored for $48 \mathrm{~h}$ in a live cell imaging system (IncuCyte ${ }^{\circledR}$, Sartorius, Michigan, MI, USA) following treatment with increasing concentrations of the compound $(0.47-40 \mu \mathrm{M})$ and compared to vehicle-treated cells. As shown in Figure 3a, dose-dependent inhibition of the proliferation of A431 cells was observed, with the highest concentration applied $(30 \mu \mathrm{M})$ leading to complete inhibition. Similar observations were made for treated A549 and LNCaP cells (Supplementary Materials, Figure S2). To determine the half-maximal effective concentration $\left(\mathrm{EC}_{50}\right)$ values of $4 \mathbf{p}$ in the tested cell lines, the area under the curve (AUC) values, determined for the different concentrations and normalized to control value, were plotted against the corresponding concentrations. Nonlinear regression analysis of the resulting dose-response plots was performed from which the $\mathrm{EC}_{50}$ values were obtained. The performed analysis demonstrated $\mathrm{EC}_{50}$ values of $8.4 \pm 2.8 \mu \mathrm{M}$ for A431 cells, $18.2 \pm 6.0 \mu \mathrm{M}$ for A549 cells, and $11.4 \pm 6.8 \mu \mathrm{M}$ for LNCaP cells (Figure 3b). Statistical analysis of the determined $\mathrm{EC}_{50}$ values by one-way ANOVA indicated no significant difference. Furthermore, we observed distinct morphological changes of all treated cells over the course of treatment (Figure 3c, Supplementary Materials, Figure S3). 

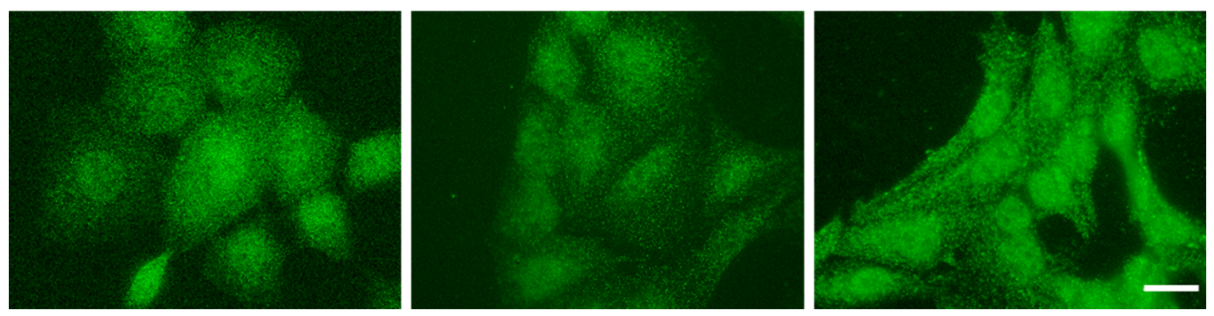

(a)

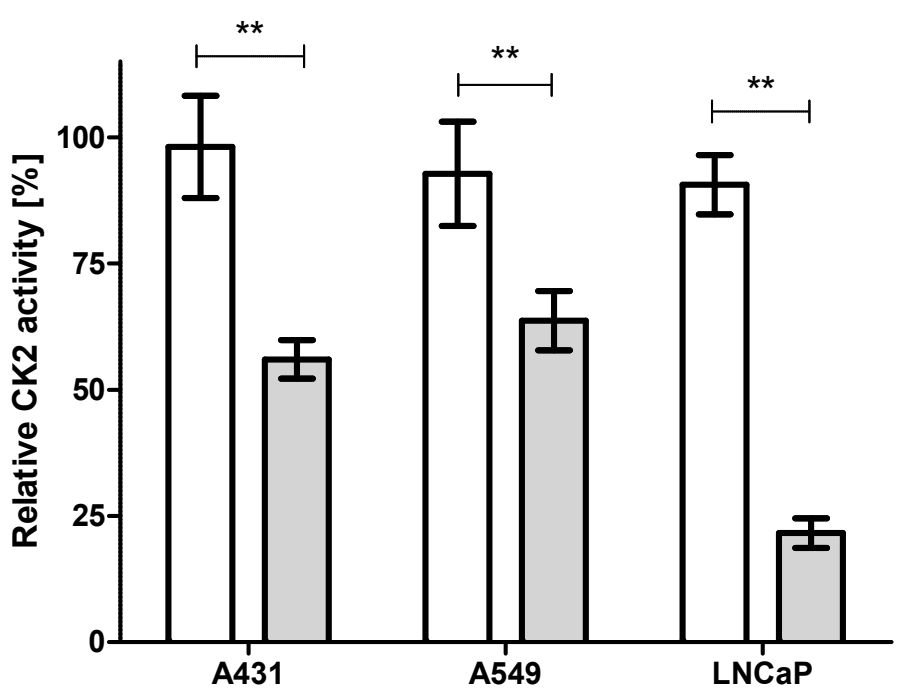

(b)

Figure 2. CK2 inhibition by $4 \mathbf{p}$ in three different cancer cell lines. (a) Immunostained A431, A549, and LNCaP cells with anti-CK2 $\alpha$ antibody (1AD9, Santa Cruz Biotechnology, Santa Cruz, CA, USA) and corresponding fluorescently labeled secondary antibody. Scale bar $=20 \mu \mathrm{M}$. (b) CK2 activity in lysates from cultured A431, A549, or LNCaP cells that were treated for $24 \mathrm{~h}$ with vehicle (1\% DMSO) or $4 \mathrm{p}$ at $1 \mu \mathrm{M}$ (white bars) and $20 \mu \mathrm{M}$ (grey bars) was determined in a capillary electrophoresis-based enzyme activity assay [35]. Data represent mean \pm SD from three independent measurements, each performed in triplicates. ${ }^{* *} p<0.01$.

Notably, we also analyzed the antiproliferative effect of $4 p$ on non-cancerous cells, namely Human Umbilical Vein Endothelial Cells (HUVECs), prepared and provided by the lab of Prof Gerke, Center for Molecular Biology of Inflammation, University of Münster. The antiproliferative $\mathrm{EC}_{50}$ of $\mathbf{4 p}$ in HUVECs was determined in an analogous manner to those determined for the cancer cell lines A431, A549, and LNCaP and was found to be $10.6 \pm 4.9 \mu \mathrm{M}$. This $\mathrm{EC}_{50}$ value of $4 \mathrm{p}$ in HUVECs is in the same range as the $\mathrm{EC}_{50}$ values determined for A431, A549, and LNCaP cells. Although the obtained results may suggest high toxicity of $4 \mathrm{p}$, the different origin and sensitivity of HUVECs have to be considered before drawing conclusions on the toxicity of $\mathbf{4 p}$. This is supported by our observation that the reference CK2 inhibitor Silmitasertib [36], which was intensively evaluated for its safety in preclinical studies and has reached clinical trials [37,38], had an $\mathrm{EC}_{50}=10.7 \pm 1.5 \mu \mathrm{M}$ on HUVECs in our experiments.

Taken together, these results indicate the dose-dependent and strong antiproliferative effects induced by $4 \mathbf{p}$ in different types of cancer cells known to be overexpressing CK2. Thus, the observed antiproliferative effects of $\mathbf{4 p}$ are likely attributed to cellular CK2 inhibition as derived from the cellular target engagement data shown in Figure $2 b$. 


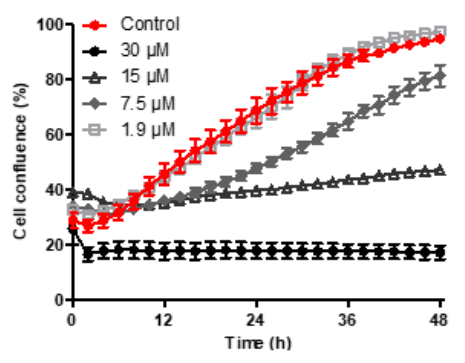

(a)

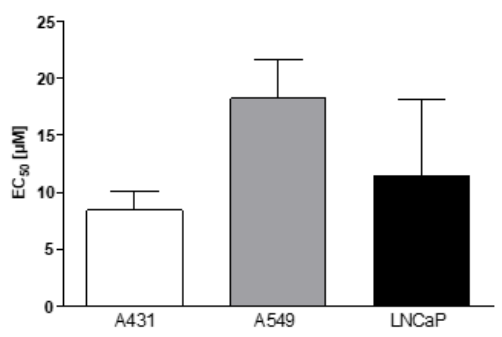

(b)

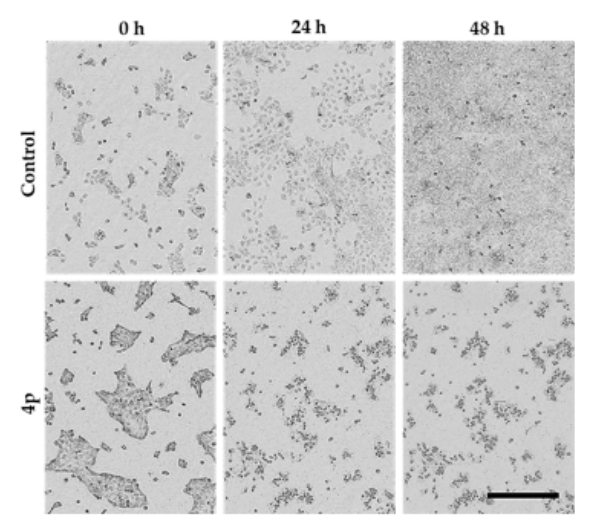

(c)

Figure 3. Investigation of the antiproliferative effect of $4 p$ in three different cancer cell lines. (a) Representative time-course of the percent confluence changes of A431 cells following treatment with $4 p$ at four different concentrations $(1.9-30 \mu \mathrm{M})$ or vehicle (1\% DMSO) for $48 \mathrm{~h}$. (b) EC 50 values of $4 \mathrm{p}$ in A431, A549, and LNCaP cells. Data represent mean \pm SD values from three independent experiments, each in triplicate. (c) Representative phase contrast images of A431 cells treated with $30 \mu \mathrm{M}$ of $\mathbf{4 p}$ or vehicle ( $1 \%$ DMSO control). Images were taken at three different time points: directly after treatment $(0 \mathrm{~h})$, at $24 \mathrm{~h}$, and $48 \mathrm{~h}$ following treatment. Scale bar $(400 \mu \mathrm{M})$ for all images is shown in black.

\subsubsection{Induction of Apoptosis}

Next, we investigated whether apoptosis represents the main mechanism of A431 cell death following treatment with $\mathbf{4 p}$. For this purpose, an inert non-fluorescent caspase-3/7 substrate that freely crosses the cell membrane was added to the treated cultured cells. Activated caspase-3/7 in apoptotic cells can cleave the added substrate and release a green DNA-binding fluorescent dye (Figure 4a). Cells showing fluorescently-labeled nuclei were counted using IncuCyte ${ }^{\circledR}$ S3 live-cell imaging system reflecting the extent of apoptotic events in wells of the treated cells. Here, the number of apoptotic cells showed a slight but statistically significant increase after treatment with $1 \mu \mathrm{M}$ of $4 \mathrm{p}$. On the other hand, cells treated with $20 \mu \mathrm{M}$ showed an almost two-fold increase in apoptotic events within the first $24 \mathrm{~h}$ following treatment as compared to vehicle control-treated cells (Figure $4 \mathrm{~b}$ ). These results reflect a high degree of activation of caspase 3/7 in response to cell death signals triggered by treatment of A431 cells with $4 p$. In contrast, our previous observations in MCF7 cells revealed characteristic morphological features of apoptosis upon treatment with $100 \mu \mathrm{M}$, but not with $20 \mu \mathrm{M}$, of $4 \mathbf{p}$ [33]. This discrepancy might be due to the fact that activated caspase-3/7 measured in the current study can accurately reflect early apoptotic events in cells, unlike the subjective examination of changes in nuclear size/shape. 


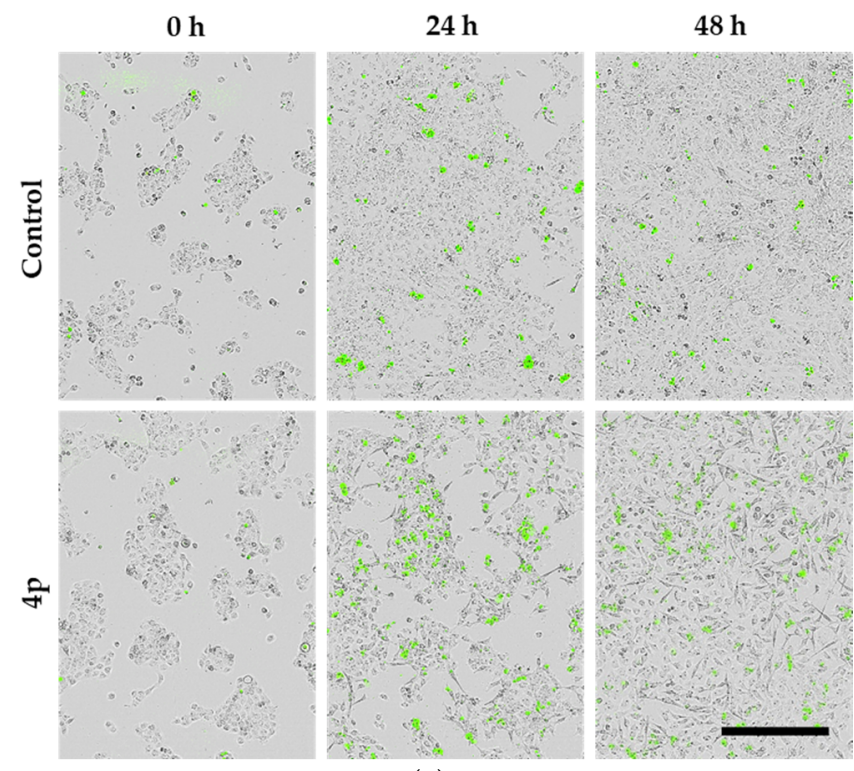

(a)

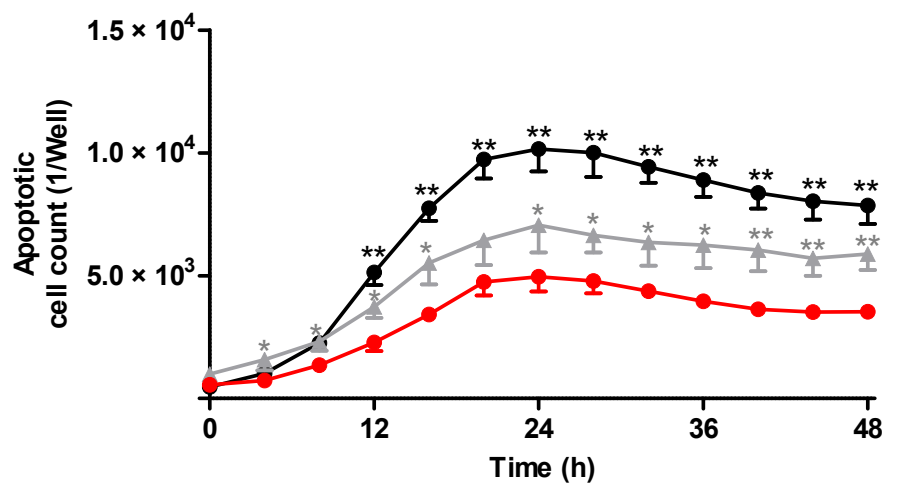

(b)

Figure 4. Induction of apoptosis by $4 p$ in cultured A431 cells. (a) Representative phase contrast images of A431 cells cultured in a 96-well plate and treated with $20 \mu \mathrm{M}$ of $4 \mathbf{p}$ or vehicle (1\% DMSO control). All wells received IncuCyte ${ }^{\circledR}$ caspase-3/7 green dye at a final concentration of $5 \mu \mathrm{M}$ simultaneously. Images were taken at three different time points: directly after treatment $(0 \mathrm{~h})$, at $24 \mathrm{~h}$, and $48 \mathrm{~h}$ following treatment. Green dots in the images represent apoptotic cells. Scale bar $(400 \mu \mathrm{m})$ for all images is shown in black. (b) Monitoring of apoptotic events in cells treated with either $1 \mu \mathrm{M}$ (gray) or $20 \mu \mathrm{M}$ (black) of $4 \mathbf{p}$, compared to control (red) over a period of $48 \mathrm{~h}$. Data represent mean $\pm \mathrm{SD}$ from an experiment with three replicates. ${ }^{*} p<0.05,{ }^{* *} p<0.01$.

\subsubsection{Inhibition of Cell Migration}

The potential of certain tumors to metastasize is closely associated with the ability of tumor cells to migrate and invade adjacent tissues. Upregulation of CK2 has been associated with the cytoskeletal reorganization and acquiring a migratory phenotype [39-44]. To assess the effect of $4 p$ on the migration capacity of A549 lung cancer cells, we examined the rate of cell migration following the induction of homogenous scratch wounds in 96-well plates. Monitoring of the induced scratch wounds for $48 \mathrm{~h}$ following treatment with $4 \mathrm{p}$ at $10 \mu \mathrm{M}$ revealed the impaired ability of A549 cells to migrate into the wound area while control cells that received 1\% DMSO were able to completely seal the wound after $48 \mathrm{~h}$ (Figure 5a). To exclude the possibility that $4 \mathrm{p}$-induced impairment of cell migration at $10 \mu \mathrm{M}$ is due to antiproliferative effect and not a direct anti-migratory effect, we examined the effect of $4 \mathbf{p}$ at a concentration of $1 \mu \mathrm{M}$, which exhibits a very weak antiproliferative effect per se. Again, we could observe a statistically significant decrease in the percentage relative wound density (i.e., 
the ratio of the occupied area to the total area of the initial wound region) in the treated wells, compared to control (Figure $5 b$ ). These results suggest that $4 \mathbf{p}$ has a direct inhibitory effect on cell migration, most likely due to inhibition of CK2 activity.
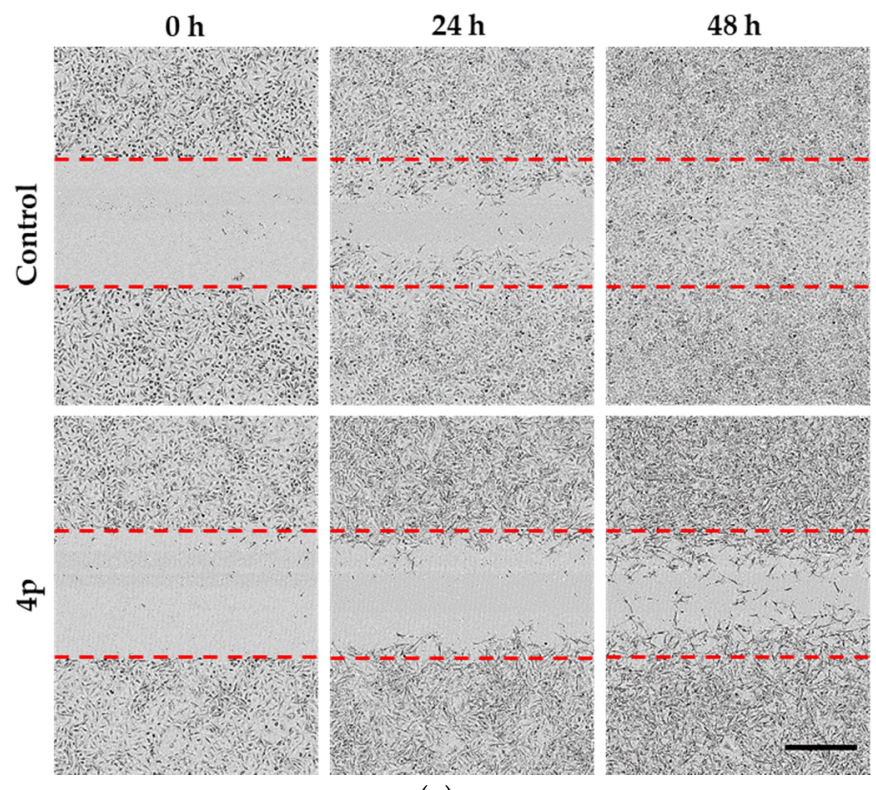

(a)

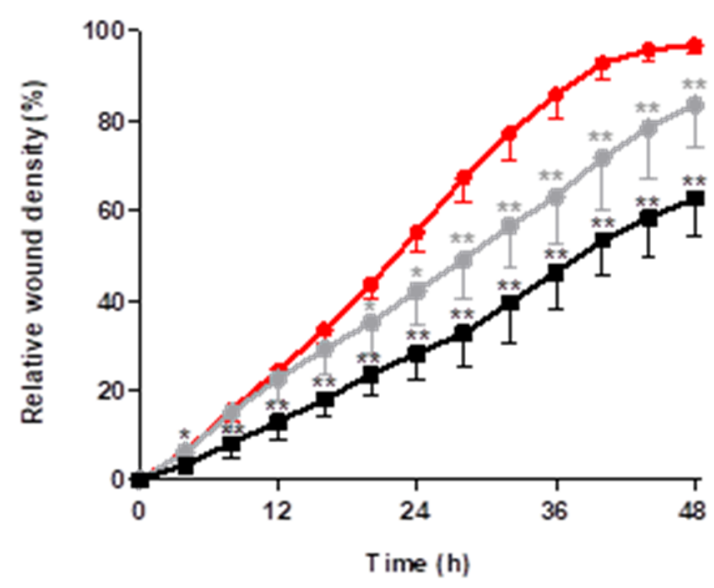

(b)

Figure 5. Inhibition of migration of A549 cells in a scratch wound assay. (a) Representative phase contrast images of scratch wounds in A459 cell layer grown to 100\% confluence in 96-well imaging plates. Cells were treated with either vehicle (1\% DMSO) or $10 \mu \mathrm{M} 4 \mathbf{p}$, and the wound closure was examined directly after treatment $(0 \mathrm{~h})$, at $24 \mathrm{~h}$, and $48 \mathrm{~h}$ following treatment. Dashed red lines represent the initial wound width. Scale bar $(400 \mu \mathrm{M})$ for all images is shown in black. (b) Timecourse of the relative wound density for cells treated with $4 \mathrm{p}$ at $1 \mu \mathrm{M}$ (gray) and $10 \mu \mathrm{M}$ (black) or vehicle control (1\% DMSO, red). Data represent mean \pm SD from an experiment with three replicates. ${ }^{*} p<0.05,{ }^{* *} p<0.01$.

\subsubsection{Evaluation of Anticancer Effects in 3D Tumor Model}

Next, we investigated the effects of $\mathbf{4 p}$ on the growth and integrity of multicellular tumor spheroids from A549 cell line. Spheroids have the ability to mimic the 3D structure of tumors and thereby serve as useful models for evaluating responses to anticancer drugs [45-47]. Here, spheroids were grown in 96-well plates for 72-96 h before treatment with $50 \mu \mathrm{M}$ of $4 \mathbf{p}$ or vehicle ( $0.5 \%$ DMSO). Monitoring of the treated spheroids revealed the development of a steadily growing diffuse outer layer of cells starting to appear $48 \mathrm{~h}$ 
after treatment with $4 \mathbf{p}$ (Figure 6). An accurate estimation of the spheroid growth was not possible since this loosely attached layer to the spheroid core led to an overestimation of spheroid size. Each well received simultaneously $250 \mathrm{nM}$ of IncuCyte ${ }^{\circledR}$ cytotox red fluorescent dye to demonstrate the cytotoxic effect of $\mathbf{4 p}$ on the treated spheroids. This dye did not perturb cell growth and yielded little intrinsic fluorescent signal in healthy cells. However, it permeated unhealthy cells with impaired plasma membrane integrity and bound DNA yielding a 100-1000-fold increase in fluorescence signals. Examination of the red fluorescence signals in the cultured A549 spheroids showed higher and uniformly distributed fluorescence signals in $4 \mathbf{p}$ treated spheroids indicating a high number of dead cells over the exposed surface of the spheroids (Supplementary Materials, Figure S4). On the other hand, control spheroids demonstrated weak red fluorescence mostly localized to the necrotic core and not to the periphery of the spheroids (Supplementary Materials, Figure S4). Interestingly, a large proportion of the detached cells from the core of treated spheroids did not show red fluorescent signals, indicating that these cells were not dead. Notably, Virgone-Carlotta et al. [48] reported recently similar effects for the chemotherapeutic agent 5-flurouracil (5-FU). In that study, the ability of 5-FU to induce an anti cohesive effect on multicellular spheroids from the colorectal carcinoma cell lines HCT116 and SW48, following treatment with $10 \mu \mathrm{M}$ of the drug, was described. The impaired spheroid cohesion in response to 5-FU was attributed to the ability of the drug to interfere with cell-cell and cell-matrix interaction in spheroids and was taken as a measure of the sensitivity of these cells to 5 -FU. Similar to 5 -FU, $\mathbf{4 p}$ demonstrated a strong anti cohesive effect and resulted in detaching a mixture of dead and viable cells from the spheroid core. These viable detached cells seem to be resistant to the cytotoxic effects of $4 \mathbf{p}$ and thereby simulating the drug-resistant cell subpopulations in tumor entities, which would therefore require multidrug treatment to eradicate them.

$\mathbf{O h}$

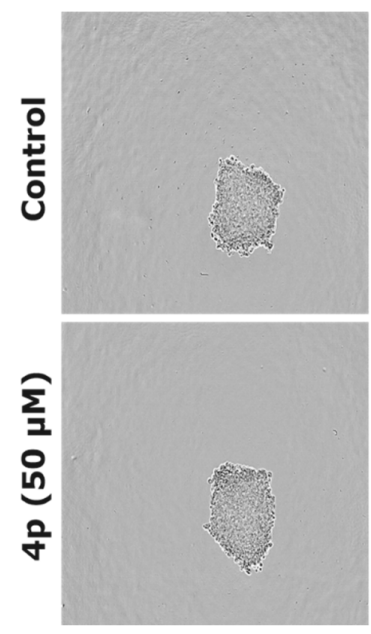

$24 \mathrm{~h}$

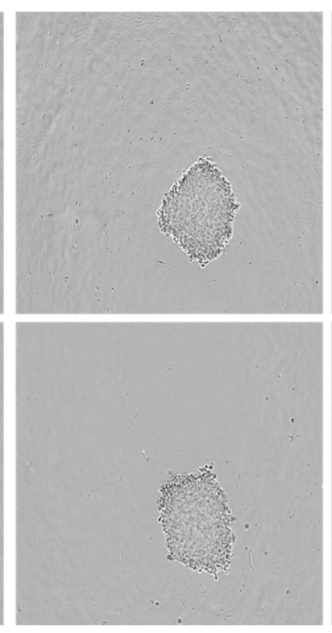

$48 \mathrm{~h}$

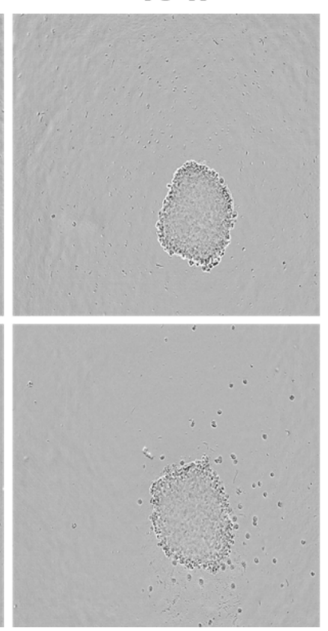

$72 \mathrm{~h}$

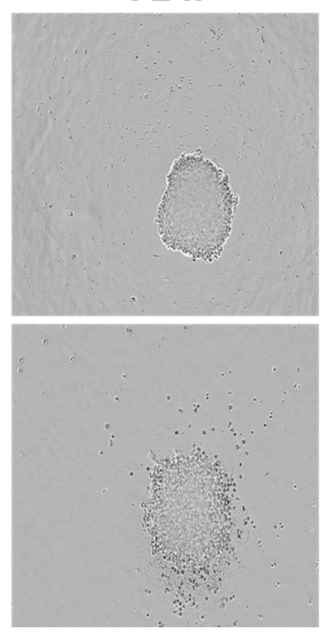

$96 \mathrm{~h}$

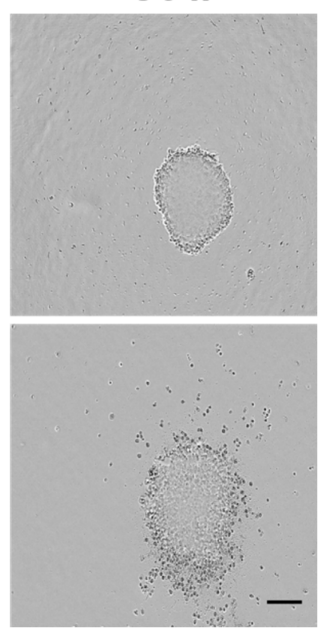

Figure 6. Effect of $4 p$ on the integrity of multicellular spheroids from A549 cell line. Representative phase-contrast images from time-lapse imaging of spheroids treated with either $50 \mu \mathrm{M}$ of $4 \mathrm{p}$ or vehicle control (0.5\% DMSO). Increasing numbers of detached cells from the spheroid core start to appear at $48 \mathrm{~h}$ post-treatment with $4 \mathrm{p}$. The figure is representative of three independent experiments, each performed at least in duplicates. Scale bar $(200 \mu \mathrm{M})$ for all images is shown in black.

\subsection{Investigation of In Vitro Pharmacokinetic Properties \\ 2.3.1. Cellular Uptake}

To better assess the suitability of $4 \mathbf{p}$ as a potential anticancer drug, we investigated both the uptake in cancer cells and the metabolic stability of the compound. The changes in the intracellular concentration of $\mathbf{4 p}$ in cultured A431 cancer cells were studied in both time- and concentration-dependent manners. First, the concentration of $4 p$ was determined in lysates from A431 cells using LC-MS/MS following preincubation of cells with $1 \mu \mathrm{M}$ 
of the compound for 1,5 , and $12 \mathrm{~h}$. Here, an intracellular concentration of approximately $5 \mu \mathrm{M}$ was reached at $1 \mathrm{~h}$ post-treatment and continued to decline over the later time points to reach a value of $2.8 \mu \mathrm{M}$ at $12 \mathrm{~h}$ post-treatment (Figure $7 \mathrm{a}$ ). Furthermore, we observed approximately a four-fold increase in the intracellular concentration of $4 \mathbf{p}(14 \mu \mathrm{M})$ upon increasing the extracellular concentration of the compound to $3 \mu \mathrm{M}$ (Figure $7 \mathrm{~b}$ ). These results indicate the rapid uptake of the compound by A431 cells and suggest that the observed uptake was not due to a saturable transport process.

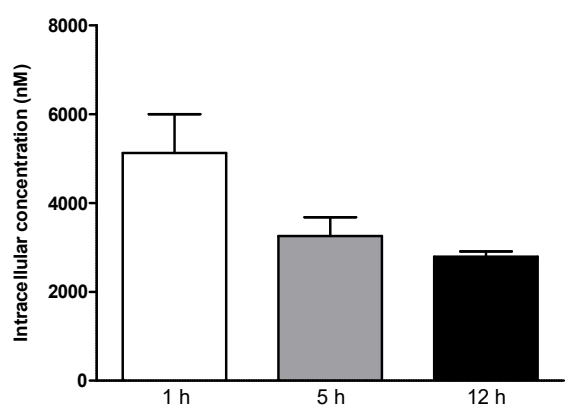

(a)

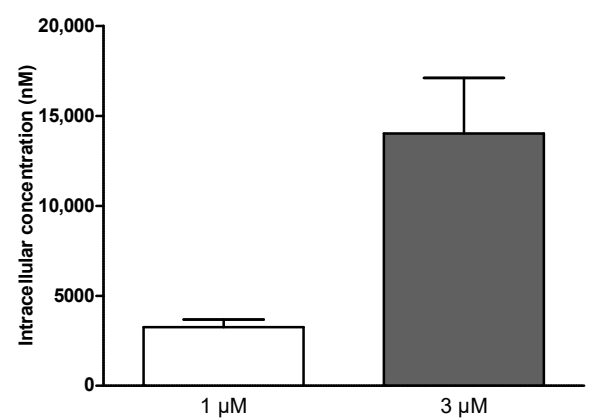

(b)

Figure 7. Uptake of $\mathbf{4 p}$ in A431 cancer cell line. (a) Time-dependent changes in the intracellular concentration of $4 \mathrm{p}$ in the presence of $1 \mu \mathrm{M}$ of extracellular concentration of the compound. Cells were harvested at 1, 5, and $12 \mathrm{~h}$ post-treatment, counted, and lysed. (b) Concentration-dependent changes in the intracellular concentration of $4 \mathrm{p}$ in the presence of 1 or $3 \mu \mathrm{M}$ of extracellular concentration of the compound. Cells were harvested at $5 \mathrm{~h}$ post-treatment, counted, and lysed. In both (a,b), the concentration of $4 p$ in the soluble fraction of the lysate was determined via LC-MS/MS using matrix calibration. Data represent mean \pm SD from an experiment with three replicates.

The observed higher intracellular concentration of $4 p$ as compared to the concentration of the compound in the cell culture medium indicates intracellular accumulation of the compound following its cellular uptake. Cellular retention of drugs has been previously described for kinase inhibitors, for example, imatinib, and is considered beneficial from a pharmacokinetic perspective [49]. A possible reason for this observed accumulation of $\mathbf{4 p}$ might be the binding of the compound to cellular structures, e.g., plasma membrane [50], or inclusion in lipid droplets [51], leading to the retention of the substance in the treated cells. It would be important to investigate the mechanism(s) of cellular uptake as well as the subcellular distribution of $4 p$ to clarify this observation.

\subsubsection{In Vitro Metabolism Analysis}

Next, the phase I metabolic stability of $4 \mathbf{p}$ was assessed using imipramine, which is known to be metabolically labile per se [52], as a reference compound. Following incubation of $25 \mu \mathrm{M}$ of each compound with mouse liver microsomal homogenate in the presence of cofactors, essential for phase I metabolic reactions, the percent parent ion was determined in LC-MS/MS at different time points, relative to the initial level of parent ion $(t=0)$. Here, the parent ion of $4 p$ almost completely disappeared after 15 min of incubation, while imipramine demonstrated a gradual decrease in the parent ion level up to the complete disappearance of its corresponding parent ion after $120 \mathrm{~min}$ (Figure $8 \mathrm{a}$ ). These results indicate that $4 \mathbf{p}$ was extensively metabolized in phase I reactions. Therefore, attempts were made to identify the major phase I as well as phase II metabolites of $4 \mathbf{p}$, whereby glucuronidation was analyzed as a representative for phase II metabolic reactions. Several mono- and dihydroxylated metabolites of $4 \mathbf{p}$ (Figure $8(\mathrm{~b} 1,2)$ ) and its deprenylated derivative (Figure 8(b3-6)) could be identified, with the hydroxyl groups being added to ring $\mathrm{A}$ and/or ring $\mathrm{D}$ of the indeno[1,2-b]indole backbone. Furthermore, some of the hydroxylated metabolites were found to be glucuronidated in our experiments (Figure $8(\mathbf{b} 7,8)$ ), suggesting that hydroxylation and glucuronidation may represent the 
major metabolic pathways for $4 \mathbf{p}$. These metabolites were not observed in control samples that did not contain NADPH as a cofactor for phase I metabolic enzymes and UDPGA as a cofactor for phase II metabolic enzymes in our study. This indicates the stability of $4 p$ in the absence of active metabolic processes.

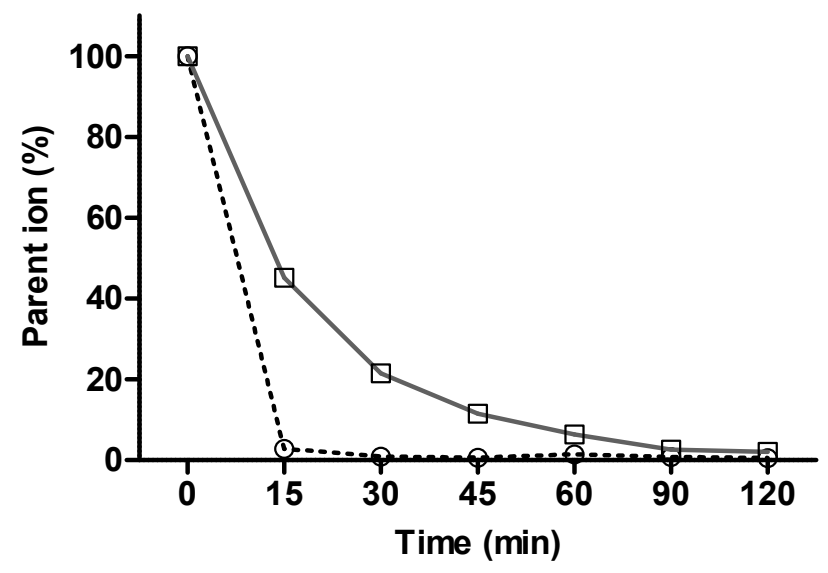

(a)

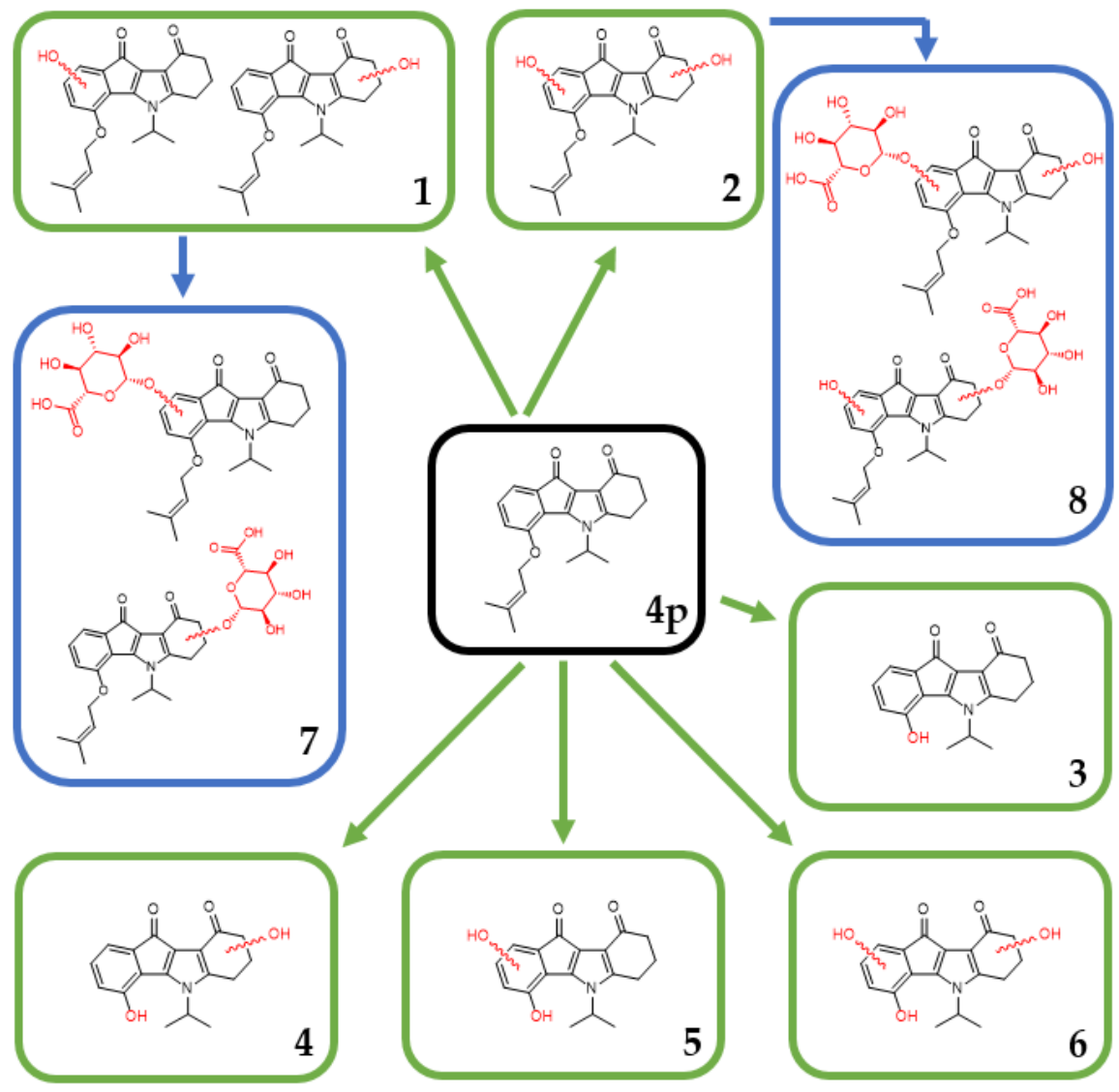

(b)

Figure 8. In vitro metabolism study of $4 \mathbf{p}$. (a) Metabolic stability profile of $4 \mathbf{p}$ (dashed line) compared to that of imipramine (solid line). Both compounds were incubated with mouse liver microsomal fractions and NADPH for $120 \mathrm{~min}$. The disappearance of the parent ion over time was measured in LC-MS/MS and normalized to the amount of parent ion at the start of the incubation $(t=$ zero). (b) Schematic presentation of major identified metabolites of $4 p$ as elucidated from MS spectra following incubation with mouse liver microsomes and cofactors for phase I metabolism enzymes (green rectangles) and UDPGA to study glucuronidation (blue rectangles). 
Importantly, the approach taken to study the metabolism of $4 \mathbf{p}$ in this study allowed the determination of the masses of the metabolites, but not the exact position of identical substituent as, for example, hydroxyl groups. In this analysis, it was also not possible to quantify the amount of the different metabolites obtained. Preliminary HPLC separation allowed, however, a distinction between the individual metabolites with similar masses, and thereby, we were able to determine the number of obtained $4 \mathbf{p}$ metabolites (Supplementary Materials, Table S1, Figures S5-S11). It would be interesting in future studies to structurally characterize and test the CK2 inhibitory activity and cellular effects of these metabolites, particularly 1 and 2, which were still bearing both the prenyloxy and isopropyl substitutions required for high CK2 inhibitory activity. Taken together, these results indicate the metabolic instability of $\mathbf{4 p}$ and hints at the presence of active hydroxylated metabolites of the compound.

\section{Materials and Methods}

\subsection{Chemicals}

All chemicals were purchased in the highest available purity. $4 \mathbf{p}$, synthesized as described before in Gozzi et al. [33], was solved in dimethyl sulfoxide (DMSO) at a concentration of $10 \mathrm{mM}$ and stored at $-20^{\circ} \mathrm{C}$.

\subsection{Cell Culture}

Human epidermoid carcinoma cell line A431 and human lung carcinoma cell line A549 were cultured in DMEM high glucose medium (Life Technologies, Waltham, MA, USA) supplemented with $10 \%$ fetal calf serum (FCS). Both cell lines were kindly provided by Prof. Dr. Angelika Barnekow (Institute for Neuro- and Behavioural Biology, Westfälische Wilhelms-Universität, D-48149 Münster, Germany). Human prostate carcinoma cell line LNCaP, kindly provided by Prof. Dr. Claudia Götz (Department of Medical Biochemistry and Molecular Biology, Saarland University, D-66424 Homburg, Germany), was cultured in RPMI 1640 GlutaMax (Life Technologies, Waltham, MA, USA) supplemented with 10\% FCS. All three cell lines were cultured at $37{ }^{\circ} \mathrm{C}$ in a humidified atmosphere of $5 \% \mathrm{CO}_{2}$. Cells were cultured in $100 \mu \mathrm{L}$ cell culture medium in 96-well plates and $2 \mathrm{~mL}$ in 6-well plates (Cellstar, Greiner, Darmstadt, Germany).

\subsection{Determination of Intracellular CK2 Activity}

The effect of $4 \mathbf{p}$ on CK2 activity in cancer cells was determined using a modified protocol from the one described before by Schneider et al. [53]. Briefly, cells were cultured in 6-well plates for $48 \mathrm{~h}$. Afterward, the medium was replaced with a $2 \mathrm{~mL}$ fresh cell culture medium containing 1 or $20 \mu \mathrm{M} 4 \mathbf{p}$ or vehicle control (1\% DMSO) followed by $24 \mathrm{~h}$ incubation at $37{ }^{\circ} \mathrm{C}$ in a humidified atmosphere of $5 \% \mathrm{CO}_{2}$. Subsequently, cells were harvested and suspended in lysis buffer $(50 \mathrm{mM}$ Tris $/ \mathrm{HCl}(\mathrm{pH} 7.5), 0.5 \%$ sodium desoxycholate, $0.15 \mathrm{mM} \mathrm{NaCl}, 1 \mathrm{mM} \mathrm{Na} \mathrm{VO}_{4}, 0.5 \mathrm{mM} \mathrm{NaF}, 0.8 \mu \mathrm{M}$ aprotinin, $10 \mu \mathrm{M}$ pepstatin A, $20 \mu \mathrm{M}$ leupeptin, $0.1 \mathrm{mM}$ PMSF, $1 \mathrm{mM}$ benzamidine, $1 \%$ Triton $\mathrm{X}-100)$. The protein concentration of the soluble fractions of the lysates was determined using a Bradford method (Roti-Quant, Roth, Karlsruhe, Germany). For each sample, $90 \mu \mathrm{g}$ of protein was diluted in $80 \mu \mathrm{L}$ kinase buffer $(50 \mathrm{mM}$ Tris $/ \mathrm{HCl} \mathrm{pH} 7.5,100 \mathrm{mM} \mathrm{NaCl}, 10 \mathrm{mM} \mathrm{MgCl} 2)$ and preincubated at $37^{\circ} \mathrm{C}$ for $10 \mathrm{~min}$. The reaction was started by mixing samples with $120 \mu \mathrm{L}$ assay buffer (25 mM Tris/ $\mathrm{HCl}(\mathrm{pH} 8.5), 150 \mathrm{mM} \mathrm{NaCl}, 5 \mathrm{mM} \mathrm{MgCl} 2,190 \mu \mathrm{M}$ FITC-RRRDDDSDDD, $100 \mu \mathrm{M}$ ATP). Samples were incubated for $15 \mathrm{~min}$ at $37^{\circ} \mathrm{C}$ before the kinase reaction was terminated by adding $5 \mathrm{mM}$ EDTA and incubating samples on ice. Samples were analyzed via capillary electrophoresis (CE) as described in Gratz et al. 2010 [35] and detected using a laser-induced fluorescence (LIF) detector. Relative CK2 activity was calculated in each sample using the ratio of AUC values of detected product and substrate peaks and normalized to that of vehicle control ( $1 \%$ DMSO). The latter was set as $100 \%$ activity. 


\subsection{IncuCyte ${ }^{\circledR}$ Cell Proliferation Assay}

A431, A549, and LNCaP cells were cultured in 96-well plates to a confluence of approximately $30 \%$. Then, the culture medium in each well was removed and replaced with $100 \mu \mathrm{L}$ fresh medium containing vehicle control (1\% DMSO) or $4 \mathrm{p}$ in at least eight different concentrations. Afterward, cells were placed in an IncuCyte ${ }^{\circledR}$ S3 live-cell imaging system (Sartorius, Ann Arbor, MI, USA) at $37^{\circ} \mathrm{C}$ in a humidified atmosphere of $5 \% \mathrm{CO}_{2}$ for a total period of $48 \mathrm{~h}$. Microscopic phase contrast images of all wells were taken at $2 \mathrm{~h}$ intervals with a ten-fold lens (four images per well). The percent cell confluence in each well was determined for all time points using the IncuCyte S3 2017A software. GraphPad Prism 5 software (GraphPad software, La Jolla, CA, USA) was used to determine the area under the obtained growth curves (AUC). The percent confluence at the beginning of each growth curve was set as the baseline, respectively. The AUC values of the obtained curves were normalized to the corresponding AUC of the vehicle control and plotted against the logarithmic values of the applied $4 \mathbf{p}$ concentrations. A nonlinear regression analysis was performed to determine an $\mathrm{EC}_{50}$ value for each cell line using GraphPad Prims 5 software.

\subsection{IncuCyte ${ }^{\circledR}$ Cell Apoptosis Assay}

A431 cells were seeded into 96-well plates and cultured until a confluence of 30-40\% was reached. Subsequently, the culture medium in the wells was removed and replaced with $100 \mu \mathrm{L}$ fresh medium containing either 1 or $20 \mu \mathrm{M}$ of $4 \mathbf{p}$ while control wells received $1 \%$ DMSO. The added solution to each well contained $5 \mu \mathrm{M}$ of a green caspase $3 / 7$ apoptosis reagent (Sartorius, Ann Arbor, MI, USA). This fluorescent dye is bound to a quencher via a peptide chain. The enzymes caspase 3 and 7 , which are only active during the induction of apoptosis in eukaryotic cells, are able to cleave this peptide chain. Subsequently, the dye intercalates into the DNA in the nucleus of the apoptotic cells and its fluorescence signal is detectable. After treatment, cells were stored in an IncuCyte ${ }^{\circledR}$ S3 live-cell imaging system for $48 \mathrm{~h}$ at $37^{\circ} \mathrm{C}$ and $5 \% \mathrm{CO}_{2}$. Fluorescence microscopy images of the wells were taken every $2 \mathrm{~h}$ with a ten-fold lens (four images per well) using the green fluorescence channel of the IncuCyte ${ }^{\circledR}$ S3 live-cell imaging system (excitation 440-480 nm, emission 504-544 nm). The number of apoptotic cells was derived from the number of green fluorescent events determined with the IncuCyte ${ }^{\circledR}$ 2017A Rev2 software.

\subsection{IncuCyte ${ }^{\circledR}$ Scratch Wound Migration Assay}

Image-lock plates with 96-wells (Sartorius, Ann Arbor, MI, USA) were coated with a collagen-I solution $(300 \mu \mathrm{g} / \mathrm{mL})$ in $0.02 \mathrm{M}$ acetic acid to study the migration of A549 lung carcinoma cells. Subsequently, $2.5 \times 10^{4}$ A549 cells per well were seeded into the prepared image-lock plates. The cells were cultured at $37^{\circ} \mathrm{C}$ and $5 \% \mathrm{CO}_{2}$ until $100 \%$ confluence was achieved. Next, a wound was created in the center of each well using a WoundMaker ${ }^{\mathrm{TM}}$ (Sartorius, Ann Arbor, MI, USA) followed by washing the wells twice with $120 \mu \mathrm{L}$ of the pre-warmed medium. Wells then received $100 \mu \mathrm{L}$ of fresh medium containing either vehicle ( $1 \%$ DMSO) or $4 \mathbf{p}$ at two different concentrations (1 and $10 \mu \mathrm{M})$. Microscopic phase contrast images were then taken at $2 \mathrm{~h}$ intervals over a 48 -h period in IncuCyte ${ }^{\circledR}$ S3 live cell imaging system and analyzed using the IncuCyte ${ }^{\circledR}$ 2017A Rev2 software to calculate the relative wound density in each well at the corresponding time points.

\subsection{IncuCyte ${ }^{\circledR} 3 D$ Spheroid Imaging}

Multicellular spheroids from the A549 cell line were initiated and cultured according to the protocol of Friedrich et al. [54] to evaluate the effects of $4 \mathbf{p}$ on a 3D tumor model. Briefly, 96-well plates were coated with $45 \mu \mathrm{L}$ of sterile $1 \%$ agarose solution, left to solidify for $10 \mathrm{~min}$ followed by seeding of $2.0 \times 10^{3}$ cells/well in $200 \mu \mathrm{L}$ of culture medium. Cells were then incubated at $37^{\circ} \mathrm{C}$ in a humidified atmosphere of $5 \% \mathrm{CO}_{2}$ to allow spheroid initiation and left to grow for $72-96 \mathrm{~h}$. On the day of treatment, $125 \mu \mathrm{L}$ of culture medium were carefully removed from each well followed by the addition of $75 \mu \mathrm{L}$ of fresh medium containing $2 \times$ of the desired final concentrations of $4 p(50 \mu \mathrm{M})$ or vehicle $(0.5 \%$ DMSO) 
and IncuCyte ${ }^{\circledR}$ cytotox red fluorescent dye (250 nM) (Sartorius, Ann Arbor, MI, USA). Cultured spheroids were monitored for $96 \mathrm{~h}$ using IncuCyte ${ }^{\circledR}$ S3 live-cell imaging system maintained at $37{ }^{\circ} \mathrm{C}$ and $5 \% \mathrm{CO}_{2}$ using both phase contrast and red fluorescence channels.

\subsection{Uptake Analysis}

Cells were seeded in 6-well plates at a density of $5.0 \times 10^{5}$ per well and cultured for $48 \mathrm{~h}$ at $37^{\circ} \mathrm{C}$ and $5 \% \mathrm{CO}_{2}$. Subsequently, the complete medium in each well was removed and replaced with a $2 \mathrm{~mL}$ fresh medium containing 1 or $3 \mu \mathrm{M} 4 \mathrm{p}$. Cells were incubated with $4 \mathbf{p}$ for 1,5 , or $12 \mathrm{~h}$. Then, cells were washed with PBS and detached from the wells using trypsin/EDTA. The obtained suspensions of cells were then centrifuged for $5 \mathrm{~min}$ at $700 \times g$ and $4{ }^{\circ} \mathrm{C}$. The number of cells in the resulting pellet of each sample was determined using an automated cell counter (Scepter ${ }^{\circledR}$, Merck, Darmstadt, Germany). After washing with PBS, cells were lysed in $100 \mu \mathrm{L}$ homogenization buffer $(50 \mathrm{mM}$ Tris $/ \mathrm{HCl}(\mathrm{pH} 7.5), 1 \mathrm{mM}$ EDTA, $1 \mathrm{mM} \mathrm{Na}_{3} \mathrm{VO}_{4}, 0.5 \mathrm{mM} \mathrm{NaF}, 0.1 \mathrm{mM}$ PMSF, $1 \mathrm{mM}$ benzamidine, $1 \%$ Triton X-100). Proteins were precipitated by adding $500 \mu \mathrm{L}$ of ice-cold acetonitrile/methanol $1 / 1(v / v)$ and separated by centrifugation for $30 \mathrm{~min}$ at $4{ }^{\circ} \mathrm{C}$ and $20,000 \times \mathrm{g}$. Five hundred microliters of the supernatants were evaporated to dryness using a vacuum centrifuge (Christ) for $1.5 \mathrm{~h}$ at $50{ }^{\circ} \mathrm{C}$ under full vacuum and suspended in $100 \mu \mathrm{L}$ acetonitrile $/ \mathrm{H}_{2} \mathrm{O} 1 / 1(v / v)$. Samples were then transferred to micro inlets for HPLC vials (BGB, Rheinfelden, Germany) and analyzed by high-performance liquid chromatography coupled with detection via triple quadrupole mass spectrometry (HPLC-MS/MS, QTrap ${ }^{\circledR} 6500^{+}$, AB Sciex, Darmstadt, Germany).

External matrix calibration was performed for the quantitative determination of the intracellular concentration of $4 \mathbf{p}$. Intracellular concentrations were calculated as described in Rahnel et al. [55] with the following equation.

$$
c_{x}=\frac{A_{x}-b}{a} \times V_{\text {final }} \times \frac{1}{N_{\text {cells }} \times \frac{4}{3} \pi \times\left(\frac{d_{\text {cells }}}{2 \times 1000}\right)^{3}} \times 1.01
$$

where $c_{x}$ is the intracellular concentration of $4 \mathbf{p}, A_{x}$ is the area of the analyte signal in the respective chromatogram, $\mathrm{b}$ is the ordinate, and $\mathrm{a}$ is the slope of the calibration line, $\mathrm{V}_{\text {final }}$ is the final sample volume, $\mathrm{N}_{\text {cells }}$ is the cell number of the sample and $\mathrm{d}_{\text {cells }}$ is the mean diameter of the cells in the sample. The factor 1.01 takes into account the sample volume taken for cell count determination.

\subsection{In Vitro Metabolism Analysis}

The metabolic stability determination and the identification of metabolites of $4 \mathbf{p}$ were performed using a method previously described by Börgel et al. [56]. For the analysis of the metabolic stability of $4 \mathbf{p}, 25 \mu \mathrm{M}$ of the substance were dissolved in PBS supplemented with $12.5 \mathrm{mM} \mathrm{MgCl}_{2}$ and $0.5 \mathrm{mg} / \mathrm{mL}$ NADPH. Next, mouse liver microsomes were added to the reaction $\left(0.5 \mathrm{mg} / \mathrm{mL}\right.$ protein). Samples were incubated $15-120 \mathrm{~min}$ at $37^{\circ} \mathrm{C}$ and $900 \mathrm{rpm}$ in a thermomixer (Eppendorf, Hamburg, Germany). The reaction was terminated by adding $400 \mu \mathrm{L}$ ice-cold acetonitrile $/ \mathrm{H}_{2} \mathrm{O} 1 / 1(v / v)$ to each sample. Samples were centrifuged for $10 \mathrm{~min}$ at $4{ }^{\circ} \mathrm{C}$ and $20,000 \times g$. Supernatants were analyzed via HPLC-MS/MS.

Metabolites of $4 \mathbf{p}$ were identified as described above. In contrast to the metabolic stability analysis, $0.5 \mathrm{mg} / \mathrm{mL}$ UDPGA was used beside NADPH to analyze glucuronidation representative for phase II metabolism. Samples were analyzed with a high-resolution LCqToF-MS system (Bruker Daltonics, Billerica, MA, USA). The identification of metabolites of $4 \mathbf{p}$ was performed by determining molecular formulas from the exact masses of each metabolite using Data Analysis software (Bruker Daltonics, Billerica, MA, USA).

\subsection{HPLC Analysis}

For the cellular uptake and metabolism analysis, samples were investigated using a Nexera X2 high-performance liquid chromatography (HPLC) system (Shimadzu, Kyoto, 
Japan) coupled with a triple quadrupole mass spectrometer $\left(\mathrm{QTrap}{ }^{\circledR} 6500^{+}, \mathrm{AB}\right.$ Sciex, Darmstadt, Germany). A RP18 column (XSelect HSS T3, $100 \mathrm{~mm} \times 2.10 \mathrm{~mm}, 2.5 \mu \mathrm{m}$, Waters, Milford, MA, USA) was used as the stationary phase here, which was tempered to $40{ }^{\circ} \mathrm{C}$. A solvent gradient of acetonitrile $/ \mathrm{H}_{2} \mathrm{O} 10 / 90(v / v)+0.1 \%(v / v)$ formic acid $(\mathrm{A})$ and acetonitrile $/ \mathrm{H}_{2} \mathrm{O} 90 / 10(v / v)+0.1 \%(v / v)$ formic acid $(\mathrm{B})$ served as the mobile phase. The flow rate was set to $0.3 \mathrm{~mL} / \mathrm{min}$. The gradient was run as follows: $0 \% \mathrm{~B}$ to $100 \% \mathrm{~B}: 0-7 \mathrm{~min}$; $100 \%$ B 7-9 $\mathrm{min} ; 100 \%$ B to 0\% B: $9-9.5 \mathrm{~min} ; 0 \% \mathrm{~B}: 9.5-15 \mathrm{~min}$. The injection volume of the samples was $5 \mu \mathrm{L}$. Analytes were ionized via electrospray ionization (ESI) and detected in multiple reaction monitoring (MRM) mode. MS parameters were optimized on a compound-specific basis.

The metabolite identification was performed using an Ultimate 3000 RS HPLC system (Dionex, Sunnyvale, CA, USA) in combination with a high-resolution micrOTOF-Q II mass spectrometer (Bruker Daltonics, Billerica, MA, USA). The stationary phase and the solvent composition were as described above. The solvent gradient was run as follows: $0 \% \mathrm{~B}$ : 0-1 $\mathrm{min} ; 0 \%$ B to $100 \%$ B 1-12 min; $100 \%$ B: $12-14.5 \mathrm{~min} ; 100 \%$ B to $0 \%$ B: $14.5-15 \mathrm{~min} ; 0 \%$ B: $15-18 \mathrm{~min}$. The flow rate was set at $0.4 \mathrm{~mL} / \mathrm{min}$. The injection volume was $10 \mu \mathrm{L}$. Analyte ionization was performed via ESI. For metabolite identification, exact masses of ions with $m / z 70-700$ were determined.

\subsection{Statistical Analysis}

Levels of significance for comparison of two treatment groups in Figure $2 b$ or control and each treatment group in Figures $4 \mathrm{~b}$ and $5 \mathrm{~b}$ were determined using an unpaired Student's $t$-test. Comparison of the $\mathrm{EC}_{50}$ values determined in the three cell lines studied (Figure $3 \mathrm{~b}$ ) was performed by one-way ANOVA. The $p$-values are indicated in the corresponding figures as follows: ${ }^{*} p<0.05,{ }^{* *} p<0.01$. All statistical analyses were performed using GraphPad Prism 5 Software.

\section{Conclusions}

In previous work, we identified the prenyloxy-substituted indeno[1,2-b]indole, known as $4 \mathbf{p}$, as a very potent inhibitor of CK2 holoenzyme using in vitro kinase activity assay. In the present work, we provide evidence for the intracellular inhibition of CK2 in three different in vitro cancer models indicating the cellular target engagement of $4 \mathbf{p}$. Using live-cell imaging, we thoroughly investigated the biological effects of $4 p$ on several CK2mediated cellular processes associated with cancer in 2D and 3D cell cultures. $4 \mathbf{p}$ shows convincing antiproliferative, anti-migratory, and apoptosis-inducing effects and seems to disrupt cell/cell and cell/matrix interactions as indicated by the impaired cohesion of tumor spheroids. The strong anticancer effects of $\mathbf{4 p}$ suggest high intracellular concentrations of the compound, which was confirmed in the present study. We further show that $4 \mathbf{p}$ is extensively metabolized, giving rise to several hydroxylated and/or deprenylated metabolites, which can be glucuronidated, posing a challenge to improve the drug-like properties of the compound. The evaluation of the CK2 inhibitory potential and cellular activities of these metabolites should be considered for future work.

Supplementary Materials: The following are available online https:/ / www.mdpi.com/article/ 10.3390 / ph14060542/s1, Figure S1: Representative electropherogram of capillary electrophoresisbased measurements of cellular CK2 kinase activity, Figure S2: Representative time-course of the percent confluence changes of (a) A549 and (b) LNCaP cells following treatment with 4p, Figure S3: Representative phase contrast images of (a) A549 and (b) LNCaP cells treated with 4p, Figure S4: Representative red fluorescence channel images (a) and overlay with phase contrast images (b) of A549 spheroids showing the cytotoxic effect of $\mathbf{4} \mathbf{p}$, Table S1 and Figures S5-S11: Identification of $4 \mathrm{p}$ metabolites.

Author Contributions: Designed the spheroid experiments, participated in the migration experiments and prepared the manuscript, E.E.-A.; Designed and performed cellular assays and metabolic stability experiments and helped in preparation the manuscript, R.B.; Participated in the uptake and metabolic stability experiments, L.B.; Participated in the design of cellular assays, D.A.; Resynthe- 
sized and purified 4p, C.M. and Z.B.; Supervised and coordinated the chemistry part of the project, M.L.B.; Supervised and coordinated the project and wrote parts of the manuscript, J.J. All authors have read and agreed to the published version of the manuscript.

Funding: This research received no external funding.

Institutional Review Board Statement: Not applicable.

Informed Consent Statement: Not applicable.

Data Availability Statement: The data presented in this study are available in the article and Supplementary Materials.

Acknowledgments: We would like to thank K. Vieth for his support with spheroid experiments. We also deeply thank Joerg Fabian for his help in the LC-MS/MS experiments.

Conflicts of Interest: The authors declare no conflict of interest.

\section{References}

1. Burnett, G.; Kennedy, E.P. The enzymatic phosphorylation of proteins. J. Biol. Chem. 1954, 211, 969-980. [CrossRef]

2. Litchfield, D.W. Protein kinase CK2: Structure, regulation and role in cellular decisions of life and death. Biochem. J. 2003, 369, 1-15. [CrossRef] [PubMed]

3. Salvi, M.; Sarno, S.; Cesaro, L.; Nakamura, H.; Pinna, L.A. Extraordinary pleiotropy of protein kinase CK2 revealed by weblogo phosphoproteome analysis. BBA Mol. Cell Res. 2009, 1793, 847-859. [CrossRef]

4. Montenarh, M.; Götz, C. Protein kinase CK2 and ion channels (Review). Biomed. Rep. 2020, 13, 55. [CrossRef]

5. de Villavicencio-Diaz, T.N.; Rabalski, A.J.; Litchfield, D.W. Protein kinase CK2: Intricate relationships within regulatory cellular networks. Pharmaceuticals 2017, 10, 27. [CrossRef]

6. St-Denis, N.A.; Litchfield, D.W. From birth to death: The role of protein kinase CK2 in the regulation of cell proliferation and survival. Cell Mol. Life Sci. 2009, 66, 1817-1829. [CrossRef]

7. Ahmed, K.; Gerber, D.A.; Cochet, C. Joining the cell survival squad: An emerging role for protein kinase CK2. Trends Cell Biol. 2002, 12, 226-230. [CrossRef]

8. Ahmad, K.A.; Wang, G.; Unger, G.; Slaton, J.; Ahmed, K. Protein kinase CK2-a key suppressor of apoptosis. Adv. Enzym. Regul. 2008, 48, 179-187. [CrossRef]

9. Cabrejos, M.E.; Allende, C.C.; Maldonado, E. Effects of phosphorylation by protein kinase CK2 on the human basal components of the RNA polymerase II transcription machinery. J. Cell BioChem. 2004, 93, 2-10. [CrossRef]

10. Borgo, C.; Franchin, C.; Salizzato, V.; Cesaro, L.; Arrigoni, G.; Matricardi, L.; Pinna, L.A.; Donella-Deana, A. Protein kinase CK2 potentiates translation efficiency by phosphorylating eIF3j at Ser127. BBA Mol. Cell Res. 2015, 1853, 1693-1701. [CrossRef] [PubMed]

11. Dominguez, I.; Degano, I.R.; Chea, K.; Cha, J.; Toselli, P.; Seldin, D.C. CK2 $\alpha$ is essential for embryonic morphogenesis. Mol. Cell BioChem. 2011, 356, 209-216. [CrossRef] [PubMed]

12. Buchou, T.; Vernet, M.; Blond, O.; Jensen, H.H.; Pointu, H.; Olsen, B.B.; Cochet, C.; Issinger, O.G.; Boldyreff, B. Disruption of the regulatory beta subunit of protein kinase CK2 in mice leads to a cell-autonomous defect and early embryonic lethality. Mol. Cell Biol. 2003, 23, 908-915. [CrossRef]

13. Götz, C.; Montenarh, M. Protein kinase CK2 in development and differentiation (Review). Biomed. Rep. 2017, 6, 127-133. [CrossRef]

14. Souquere-Besse, S.; Pichard, E.; Filhol, O.; Legrand, V.; Rosa-Calatrava, M.; Hovanessian, A.G.; Cochet, C.; Puvion-Dutilleul, F. Adenovirus infection targets the cellular protein kinase CK2 and RNA-activated protein kinase (PKR) into viral inclusions of the cell nucleus. Microsc. Res. Tech. 2002, 56, 465-478. [CrossRef] [PubMed]

15. Bouhaddou, M.; Memon, D.; Meyer, B.; White, K.M.; Rezelj, V.V.; Marrero, M.; Polacco, B.J.; Melnyk, J.E.; Ulferts, S.; Kaake, R.M.; et al. The global phosphorylation landscape of SARS-CoV-2 infection. Cell 2020, 182, 685-712 e619. [CrossRef]

16. Yang, W.; Gibson, S.A.; Yan, Z.; Wei, H.; Tao, J.; Sha, B.; Qin, H.; Benveniste, E.N. Protein kinase 2 (CK2) controls CD4(+) T cell effector function in the pathogenesis of colitis. Mucosal Immunol. 2020, 13, 788-798. [CrossRef] [PubMed]

17. Guerra, B.; Issinger, O.G. Protein kinase CK2 in human diseases. Curr. Med. Chem. 2008, 15, 1870-1886. [CrossRef] [PubMed]

18. Bliesath, J.; Huser, N.; Omori, M.; Bunag, D.; Proffitt, C.; Streiner, N.; Ho, C.; Siddiqui-Jain, A.; O’Brien, S.E.; Lim, J.K.C.; et al. Combined inhibition of EGFR and CK2 augments the attenuation of PI3K-Akt-mTOR signaling and the killing of cancer cells. Cancer Lett. 2012, 322, 113-118. [CrossRef] [PubMed]

19. Zheng, Y.; McFarland, B.C.; Drygin, D.; Yu, H.; Bellis, S.L.; Kim, H.; Bredel, M.; Benveniste, E.N. Targeting Protein Kinase CK2 Suppresses Prosurvival Signaling Pathways and Growth of Glioblastoma. Clin. Cancer Res. 2013, 19, 6484. [CrossRef] [PubMed]

20. Richter, A.; Roolf, C.; Hamed, M.; Gladbach, Y.S.; Sender, S.; Konkolefski, C.; Knübel, G.; Sekora, A.; Fuellen, G.; Vollmar, B.; et al. Combined Casein Kinase II inhibition and epigenetic modulation in acute B-lymphoblastic leukemia. BMC Cancer 2019, 19, 202. [CrossRef] [PubMed] 
21. Wang, G.; Unger, G.; Ahmad, K.A.; Slaton, J.W.; Ahmed, K. Downregulation of CK2 induces apoptosis in cancer cells-a potential approach to cancer therapy. Mol. Cell Biochem. 2005, 274, 77-84. [CrossRef]

22. Slaton, J.W.; Unger, G.M.; Sloper, D.T.; Davis, A.T.; Ahmed, K. Induction of apoptosis by antisense CK2 in human prostate cancer xenograft model. Mol. Cancer Res. 2004, 2, 712-721.

23. Chua, M.M.J.; Ortega, C.E.; Sheikh, A.; Lee, M.; Abdul-Rassoul, H.; Hartshorn, K.L.; Dominguez, I. CK2 in cancer: Cellular and biochemical mechanisms and potential therapeutic target. Pharmaceuticals 2017, 10, 18. [CrossRef]

24. Unger, G.M.; Davis, A.T.; Slaton, J.W.; Ahmed, K. Protein kinase CK2 as regulator of cell survival: Implications for cancer therapy. Curr. Cancer Drug Tar. 2004, 4, 77-84. [CrossRef]

25. Cozza, G. The development of CK2 inhibitors: From traditional pharmacology to in silico rational drug design. Pharmaceuticals 2017, 10, 26. [CrossRef]

26. Silva-Pavez, E.; Tapia, J.C. Protein Kinase CK2 in Cancer Energetics. Front. Oncol. 2020, 10, 893. [CrossRef]

27. Bal, C.; Baldeyrou, B.; Moz, F.; Lansiaux, A.; Colson, P.; Kraus-Berthier, L.; Léonce, S.; Pierré, A.; Boussard, M.F.; Rousseau, A.; et al. Novel antitumor indenoindole derivatives targeting DNA and topoisomerase II. Biochem. Pharm. 2004, 68, 1911-1922. [CrossRef]

28. Rongved, P.; Kirsch, G.; Bouaziz, Z.; Jose, J.; Le Borgne, M. Indenoindoles and cyclopentacarbazoles as bioactive compounds: Synthesis and biological applications. Eur. J. Med. Chem. 2013, 69, 465-479. [CrossRef]

29. Hundsdörfer, C.; Hemmerling, H.J.; Götz, C.; Totzke, F.; Bednarski, P.; Le Borgne, M.; Jose, J. Indeno[1,2-b]indole derivatives as a novel class of potent human protein kinase CK2 inhibitors. Bioorgan. Med. Chem. 2012, 20, 2282-2289. [CrossRef]

30. Hundsdörfer, C.; Hemmerling, H.J.; Hamberger, J.; Le Borgne, M.; Bednarski, P.; Götz, C.; Totzke, F.; Jose, J. Novel indeno[1,2b]indoloquinones as inhibitors of the human protein kinase CK2 with antiproliferative activity towards a broad panel of cancer cell lines. Biochem. Biophys. Res. Commun. 2012, 424, 71-75. [CrossRef]

31. Haidar, S.; Marminon, C.; Aichele, D.; Nacereddine, A.; Zeinyeh, W.; Bouzina, A.; Berredjem, M.; Ettouati, L.; Bouaziz, Z.; Le Borgne, M.; et al. QSAR model of indeno[1,2-b]indole derivatives and identification of N-isopentyl-2-methyl-4,9-dioxo-4,9Dihydronaphtho[2,3-b]furan-3-carboxamide as a potent CK2 inhibitor. Molecules 2019, 25, 97. [CrossRef] [PubMed]

32. Lindenblatt, D.; Nickelsen, A.; Applegate, V.M.; Hochscherf, J.; Witulski, B.; Bouaziz, Z.; Marminon, C.; Bretner, M.; Le Borgne, M.; Jose, J.; et al. Diacritic Binding of an Indenoindole Inhibitor by CK2 $\alpha$ Paralogs Explored by a Reliable Path to Atomic Resolution CK2 $\alpha^{\prime}$ Structures. ACS Omega 2019, 4, 5471-5478. [CrossRef]

33. Gozzi, G.J.; Bouaziz, Z.; Winter, E.; Daflon-Yunes, N.; Aichele, D.; Nacereddine, A.; Marminon, C.; Valdameri, G.; Zeinyeh, W.; Bollacke, A.; et al. Converting potent indeno[1,2-b]indole inhibitors of protein kinase CK2 into selective inhibitors of the breast cancer resistance protein ABCG2. J. Med. Chem. 2015, 58, 265-277. [CrossRef] [PubMed]

34. Hochscherf, J.; Lindenblatt, D.; Witulski, B.; Birus, R.; Aichele, D.; Marminon, C.; Bouaziz, Z.; Le Borgne, M.; Jose, J.; Niefind, K. Unexpected binding mode of a potent indeno[1,2-b]indole-type inhibitor of protein kinase CK2 revealed by complex structures with the catalytic subunit CK2 alpha and its paralog CK2 alpha. Pharmaceuticals 2017, 10, 98. [CrossRef]

35. Gratz, A.; Götz, C.; Jose, J. A CE-based assay for human protein kinase CK2 activity measurement and inhibitor screening. Electrophoresis 2010, 31, 634-640. [CrossRef] [PubMed]

36. Pierre, F.; Chua, P.C.; O’Brien, S.E.; Siddiqui-Jain, A.; Bourbon, P.; Haddach, M.; Michaux, J.; Nagasawa, J.; Schwaebe, M.K.; Stefan, E.; et al. Discovery and SAR of 5-(3-chlorophenylamino)benzo[c][2,6]naphthyridine-8-carboxylic acid (CX-4945), the first clinical stage inhibitor of protein kinase CK2 for the treatment of cancer. J. Med. Chem. 2011, 54, 635-654. [CrossRef] [PubMed]

37. Zakharia, K.; Miyabe, K.; Wang, Y.; Wu, D.; Moser, C.D.; Borad, M.J.; Roberts, L.R. Preclinical In Vitro and In Vivo Evidence of an Antitumor Effect of CX-4945, a Casein Kinase II Inhibitor, in Cholangiocarcinoma. Transl. Oncol. 2019, 12, 143-153. [CrossRef]

38. D'Amore, C.; Borgo, C.; Sarno, S.; Salvi, M. Role of CK2 inhibitor CX-4945 in anti-cancer combination therapy-Potential clinical relevance. Cell Oncol. 2020, 43, 1003-1016. [CrossRef]

39. Zou, J.J.; Luo, H.S.; Zeng, Q.; Dong, Z.Y.; Wu, D.H.; Liu, L. Protein kinase CK2 alpha is overexpressed in colorectal cancer and modulates cell proliferation and invasion via regulating EMT-related genes. J. Transl. Med. 2011, 9, 97. [CrossRef] [PubMed]

40. Wang, D.; Jang, D.-J. Protein Kinase CK2 Regulates Cytoskeletal Reorganization during Ionizing Radiation-Induced Senescence of Human Mesenchymal Stem Cells. Cancer Res. 2009, 69, 8200-8207. [CrossRef]

41. D'Amore, C.; Salizzato, V.; Borgo, C.; Cesaro, L.; Pinna, L.A.; Salvi, M. A Journey through the Cytoskeleton with Protein Kinase CK2. Curr. Protein Pept. Sci. 2019, 20, 547-562. [CrossRef]

42. Kramerov, A.A.; Golub, A.G.; Bdzhola, V.G.; Yarmoluk, S.M.; Ahmed, K.; Bretner, M.; Ljubimov, A.V. Treatment of cultured human astrocytes and vascular endothelial cells with protein kinase CK2 inhibitors induces early changes in cell shape and cytoskeleton. Mol. Cell BioChem. 2011, 349, 125-137. [CrossRef]

43. Ku, M.J.; Park, J.W.; Ryu, B.J.; Son, Y.-J.; Kim, S.H.; Lee, S.Y. CK2 inhibitor CX4945 induces sequential inactivation of proteins in the signaling pathways related with cell migration and suppresses metastasis of A549 human lung cancer cells. Bioorg. Med. Chem. Lett. 2013, 23, 5609-5613. [CrossRef]

44. Xavier, C.-P.; Rastetter, R.H.; Blömacher, M.; Stumpf, M.; Himmel, M.; Morgan, R.O.; Fernandez, M.-P.; Wang, C.; Osman, A.; Miyata, Y.; et al. Phosphorylation of CRN2 by CK2 regulates F-actin and Arp2/3 interaction and inhibits cell migration. Sci. Rep. 2012, 2, 241. [CrossRef]

45. Weiswald, L.-B.; Bellet, D.; Dangles-Marie, V. Spherical Cancer Models in Tumor Biology. Neoplasia 2015, 17, 1-15. [CrossRef] [PubMed] 
46. Nunes, A.S.; Barros, A.S.; Costa, E.C.; Moreira, A.F.; Correia, I.J. 3D tumor spheroids as in vitro models to mimic in vivo human solid tumors resistance to therapeutic drugs. Biotechnol. Bioeng. 2019, 116, 206-226. [CrossRef] [PubMed]

47. Pinto, B.; Henriques, A.C.; Silva, P.M.A.; Bousbaa, H. Three-Dimensional Spheroids as In Vitro Preclinical Models for Cancer Research. Pharmaceutics 2020, 12, 1186. [CrossRef] [PubMed]

48. Virgone-Carlotta, A.; Lemasson, M.; Mertani, H.C.; Diaz, J.-J.; Monnier, S.; Dehoux, T.; Delanoë-Ayari, H.; Rivière, C.; Rieu, J.-P. In-depth phenotypic characterization of multicellular tumor spheroids: Effects of 5-Fluorouracil. PLoS ONE 2017, 12, e0188100. [CrossRef] [PubMed]

49. Lipka, D.B.; Wagner, M.C.; Dziadosz, M.; Schnöder, T.; Heidel, F.; Schemionek, M.; Melo, J.V.; Kindler, T.; Müller-Tidow, C.; Koschmieder, S.; et al. Intracellular retention of ABL kinase inhibitors determines commitment to apoptosis in CML cells. PLoS ONE 2012, 7, e40853. [CrossRef]

50. Murakami, T.; Yumoto, R. Role of phosphatidylserine binding in tissue distribution of amine-containing basic compounds. Expert Opin. Drug Metab. Toxicol. 2011, 7, 353-364. [CrossRef]

51. Zhang, I.; Cui, Y.; Amiri, A.; Ding, Y.; Campbell, R.E.; Maysinger, D. Pharmacological inhibition of lipid droplet formation enhances the effectiveness of curcumin in glioblastoma. Eur. J. Pharm. Biopharm. 2016, 100, 66-76. [CrossRef]

52. Klerman, G.L.; Cole, J.O. Clinical pharmacology of imipramine and related antidepressant compounds. Pharm. Rev. 1965, 17, 101-141.

53. Schneider, C.C.; Götz, C.; Hessenauer, A.; Günther, J.; Kartarius, S.; Montenarh, M. Down-regulation of CK2 activity results in a decrease in the level of cdc25C phosphatase in different prostate cancer cell lines. Mol. Cell BioChem. 2011, 356, 177-184. [CrossRef] [PubMed]

54. Friedrich, J.; Seidel, C.; Ebner, R.; Kunz-Schughart, L.A. Spheroid-based drug screen: Considerations and practical approach. Nat. Protoc. 2009, 4, 309-324. [CrossRef] [PubMed]

55. Rahnel, H.; Viht, K.; Lavogina, D.; Mazina, O.; Haljasorg, T.; Enkvist, E.; Uri, A. A selective biligand inhibitor of CK2 increases caspase-3 activity in cancer cells and inhibits platelet aggregation. Chemmed. Chem. 2017, 12, 1723-1736. [CrossRef] [PubMed]

56. Börgel, F.; Galla, F.; Lehmkuhl, K.; Schepmann, D.; Ametamey, S.M.; Wünsch, B. Pharmacokinetic properties of enantiomerically pure GluN2B selective NMDA receptor antagonists with 3-benzazepine scaffold. J. Pharm. Biomed. 2019, 172, 214-222. [CrossRef] 